\title{
DEVELOPMENT OF VIDEO-BASED TEACHING MATERIALS FOR SWIMMING LEARNING
}

\author{
Farizal Imansyah $^{1}$, Widya Handayani ${ }^{2}$, Jujur Gunawan Manullang ${ }^{3}$ \\ Universitas PGRI Palembang ${ }^{1,2,3}$ \\ farizal@univpgri-palembang.ac.id
}

\begin{abstract}
The low learning outcomes in learning swimming causes lecturers to have creativity to develop and utilize Information and Communication Technology in learning activities. The purpose of this research is to produce teaching materials based on learning videos and the potential effects of teaching materials so that students are able to learn independently and not be boring. The research method used was development (Development Research). The research subjects were 28 students who took part in the learning process of the Swimming Learning course. The data collection technique used a questionnaire. Data analysis using simple statistics. The results showed that there was an increase in student learning outcomes after using swimming learning videos. Thus, the learning video developed is suitable for use in swimming learning.
\end{abstract}

Keywords: teaching materials, multimedia, swimming lessons, learning videos.

Accepted: 23 th of January 2022

Correspondence author: Farizal Imansyah E-mail : farizal@univpgri-palembang.ac.id

DOI http://dx.doi.org/10.31851/hon.v5i1.7205 ${ }^{\text {do }}$

\section{(i) (2)}

Jurnal Halaman Olahraga Nusantara licensed under a Creative Commons Attribution-ShareAlike 4.0 International License.

\section{INTRODUCTION}

Pandemics that have occurred in almost all parts of the world, including in Indonesia, have created new habits in all aspects of life. In education, online learning has become something that must be applied at all levels of education from kindergarten to college. This pandemic situation proves that without face-toface learning, learning can still take place. This confirms that learning can occur anytime and anywhere by utilizing various learning sources (Anugrah, Ibrahim, \& Sukardjo, 2021).

Science and Technology (IPTEK) is now growing rapidly, this condition requires us to increase the role of technology in the educational process (Septiani $\&$ Putra, 2020). Teaching materials are a set of materials that are systematically 
arranged both written and unwritten so as to create an environment / atmosphere that allows students to learn (Departemen Pendidikan Nasional, 2006).

Learning material is the content of teaching materials that will be conveyed to students in the learning process. Meanwhile, when viewed from students, teaching materials are materials that must be mastered by students in achieving competency standards and basic competencies, which will be evaluated for their absorption using assessment instruments arranged based on indicators of achievement of learning outcomes.

With regard to learning materials, the Swimming Learning course is a compulsory subject for Physical Education study program students. Swimming learning course material is a subject related to body movement technique skills. Therefore, the swimming learning course, especially the material on swimming styles, is not sufficient with teaching materials in the form of books with text descriptions only. Technology should be carefully laid out in the space to accommodate those activites (Lee, Morrone, \& Siering, 2018). However, videobased teaching materials as technology for learning are also needed so that an understanding of swimming styles is easily understood by students.

Video is a conveyor of messages, including audio-visual media or listening media. Audio-visual based media aims to present information in a form that is fun, attractive, easy to understand, and clear (Sihkabuden, 2005). Lecturers can use video to introduce a topic, present content, provide improvements, and increase enrichment. Teaching materials or teaching materials based on learning videos are deemed necessary, in addition to being useful for facilitating the learning process of ICT-based teaching materials, they are also a reference for students as prospective teachers to have creativity for the development and use of technology in educational activities, especially in learning. Learning should be more meaningful so that students are more active and understanding of the subjects taught (Gunawan, Putri, \& Zulkardi, 2017) 
Based on the description above, it can be concluded that lecturers must have creativity to develop and utilize Information and Communication Technology in learning activities. Therefore, researchers are interested in taking the title "Development of Video-Based Teaching Materials for Swimming Learning at the PGRI University of Palembang". The purpose of this study was to develop video-based teaching materials for swimming courses that were valid, practical and had a potential effect on these teaching materials.

\section{METHOD}

This study uses a development research method, which is a research method that aims to produce certain products and test the effectiveness of these products (Sugiyono, 2012). The products developed in this study are video-based teaching materials with reference to the Akker development model and the evaluation stages using Tessmer's Formative Evaluations to obtain and produce valid and practical video-based teaching materials. The evaluation used refers to Tessmer's formative evaluation (Barlian, 2016).

The locations that will be used in this research and development are Garuda Pond and Campus B, PGRI Palembang university, with the research subjects being the second semester students of the 2019/2020 academic year with 28 students, namely: 24 male students and 4 female students. In this study, three people from class 2.A were used as the subject of one-to-one evaluation, 10 people from class 2.A for small group evaluation, and for the subject field test. whole class research 2.B.

The data collection techniques used are as follows. Interviews were conducted when developing video-based teaching materials prototypes to obtain information about validity and practicality in developing learning video-based teaching materials that are being developed. Observation, data on the practicality of instructional video-based teaching materials were also obtained through interviews with students. The one-on-one evaluation stage is carried out by using the interview method with students, an aspect that becomes a practical reference. 
Questionnaire, practicality data for teaching materials based on learning videos were obtained from a questionnaire. Questionnaires are used to obtain data about student responses and assessments of instructional video designs. Test, at the end of the lesson, students are given postest questions to determine student responses to video-based teaching materials used in learning. Then the pretest and postest data obtained were analyzed to see whether the teaching material was effectively used to improve student learning outcomes. The test is carried out at the field test stage, by giving tests at the beginning and at the end of the lesson. The form of the question is to complete the sentence and multiple choice equipped with 5 answers with 1 correct answer of 10 questions.

\section{RESULTS \& DISCUSSION}

\section{Results}

Based on data from research by interviewing students Prodi Penjas barriers faced by students are : a) has not been effective in using the media or learning method, b) limited time in the learning process, c) lecturer had difficulty in preparing instructional media course swimming suit the needs college student, d) as well as a very appropriate method of providing swimming material. Limitations of instructional media into constraints experienced for college student to understand the lecture material pool taught by lecturers, as explained verbally, so that more college students hear in the light of the lecturers, while the issue of swimming need more media and methods that attract so college students can apply freestyle swimming movements. Limited time and infrastructure in swimming courses requires a practical learning media to make it easier to understand the material to be provided. So that lecturers are required to be more creative in developing learning media. 
Table 1. Questionnaire results for the Problem Identification stage

\begin{tabular}{|c|c|c|}
\hline No & Information Obtained & $\begin{array}{l}\text { Most Answers } \\
(\%)\end{array}$ \\
\hline 1 & Students agree that swimming is interesting & 60,46 \\
\hline 2 & $\begin{array}{l}\text { Ma student has experienced difficulties in swimming } \\
\text { lectures }\end{array}$ & 75.14 \\
\hline 3 & $\begin{array}{l}\text { If students experience difficulties, have they ever } \\
\text { discussed it with the lecturer }\end{array}$ & 51.67 \\
\hline 4 & $\begin{array}{l}\text { Learning freestyle swimming is a subject that students } \\
\text { find the most difficult to understand }\end{array}$ & 42.03 \\
\hline 5 & $\begin{array}{l}\text { Lecturers have used the lecture method without involving } \\
\text { students }\end{array}$ & 36.66 \\
\hline 6 & $\begin{array}{l}\text { The lecturer has never taught using computer-based } \\
\text { media }\end{array}$ & 65.56 \\
\hline 7 & $\begin{array}{l}\text { Students are very interested in learning small lectures if } \\
\text { there is material that uses media }\end{array}$ & 76.54 \\
\hline 8 & $\begin{array}{l}\text { Lecturers use attractive media so that learning is more } \\
\text { interesting and effective }\end{array}$ & 57.22 \\
\hline 9 & $\begin{array}{lr}\text { College student assume } & \text { media-based k computer } \\
\text { and interactive video } & \text { (example: interactive } \\
\text { multimedia, video learning) } & \end{array}$ & 66.59 \\
\hline 10 & $\begin{array}{l}\text { Students strongly agree in the use of interesting, } \\
\text { innovative, creative learning media so that it will affect } \\
\text { enthusiasm and good learning outcomes }\end{array}$ & 58.49 \\
\hline
\end{tabular}

considered the most difficult for students to understand the movement . Therefore, in the development of this teaching material, the material developed is material about freestyle swimming movements.

In accordance with permasal Ahan have been described, then the answer to these problems the need for research contributions in addressing the problem of learning, so the purpose of research and product development is to produce multimedia Learning valid, practical, and effective so that they can help college student in the learning process pool can improve student learning abilities and outcomes (Taufik et al., 2021). 


\section{Media Design and Development Results}

The syllabus and RPS for even semester swimming courses contain the subject of analysis of freestyle swimming movements. In this study, researchers developed multimedia learning swimming.

Table 2. Competency standards and Competent the Basics

\begin{tabular}{ll}
\hline Competency standards & Competency standards \\
\hline 1. Analyzing freestyle movements & Analyzing freestyle movements
\end{tabular}

Selection of SK and KD is the consideration that the material contained in the SK and KD is a material that is considered to be all- student more complicated to understand. In addition, the material contained in the SK and KD is abstract and simulative material so that it requires a modeled method or activity so that it takes a lot of time and is difficult to describe in real terms by the lecturer, so that students do not absorb and understand the material. thus learning cannot be mastered by students (Alba et al., 2019)

\section{Multimedia Contents Outline}

The GBIM on swimming lesson as shown in the following table 3.

Table 3. Multimedia Contents Outline (GBIM) of Freestyle Swimming Lesson

\begin{tabular}{llll}
\hline No. & Theory & Indicator & Media \\
\hline 1 & Freestyle & - Describe freestyle swimming & Video \\
& swimming & - Analysis movements freestyle swimming & Text, \\
& & $\begin{array}{l}\text { Describes the analysis of freestyle } \\
\text { movements }\end{array}$ & Audio, \\
& & Animation \\
\hline
\end{tabular}

The table above explains that the indicators have used a variety of media, namely text, video, animation, and audio which are one of the requirements of interactive multimedia. The use of various media has been adjusted to the characteristics of these indicators.

\section{Flowchart Making Results}

Programs are created starting from the opening, the content being delivered, leaving the program (exit). The Swimming Learning multimedia flowchart is developed clearly as shown in Figure 1 below. 
GBIM which has been collated made base for designing multimedia learning area, clearly and completely in the form of text results. In the storyboard, it is found that the swimming learning multimedia contains the following menus:

a. Start (Opener)

On the start page of multimedia learning of swimming begins with a display in the form of an opening greeting so that it can attract student attention. After the opening greeting, followed by the author's bio.

b. Author Biodata

This section contains the author's biodata who examines the development of learning multimedia swimming.

c. Title page

The title page is given with the text of the title "Development of Video-Based Teaching Materials for Swimming Courses".

d. Main page

The main page presents all the menus contained in the multimedia learning swimming. The menus on the main page are instructions for use, materials, evaluation, and exit. so that students can feel comfortable in these learning activities.

e. Instructions for use

Instructions for use contain information and icons on how to use multimedia learning in swimming, so that students are able to apply multimedia to learning swimming correctly.

f. Theory

Presentation of material using visuals, namely text, images, animation, and video as well as audio information, namely narration.

g. Evaluation

Evaluation is given with the aim of testing the competence of students after carrying out learning activities using interactive multimedia learning Swimming. 
h. Exit

This menu displays a window image to return to the previous menu or click exit to exit.

At this stage the flowchart will be developed into storyboards and multimedia. Multimedia made using Macromedia Flash 8 which is assisted by several other software, namely Adobe Audition and Movie Maker. Multimedia that is made contains text, video, animation, sound, and swimming learning images.

\section{Results of Evaluation and Revision}

In the interactive multimedia development process, the first prototype was evaluated and revised. Expert evaluation (expert review) aims to see the validity of the media. Evaluation one-to-one (one to one) and e valuation by small groups (small group) aims to see practicality and potential effects. Field trials (field test) aim to see the potential effect of media on learning outcomes (Okilanda et al., 2021)

The average results of questionnaire responses of students to use multimedia learning swimming of $83.27 \%$. It can be concluded that the use of multimedia learning swimming is included in very practical criteria. At the stage of small group swimming researchers develop. At the small group stage, it can be said that prototype 2 from the results of observations of student activities during learning is good and is classified as a practical prototype. After evaluating and revising, prototype 2 turns into prototype 3 which then be tested at the field test stage.

The average value achieved in the pretest students is 68,09 categories Enough, while for the posttest results obtained average value of students of 84,35 with categories well. If the student's post-test score one by one is compared with the score that the student has to achieve, which is 80 , it means that all students have succeeded with the overall predicate well. Judging from the comparison of the mean score of students at the pretest of 68,09 and the posttest of 84,35 means that there is an increase of 16,26. To find the gain score. Based on the analysis, it 
is found that the $\mathrm{N}$-gain is 1,03 , if $1,03 \geq 0.7$, it is included in the high category.

This shows that the multimedia learning pool that the researchers developed has a potential effect on student learning outcomes. In addition, observations were made at each meeting. This is done to see student activities in the learning process.

\section{DISCUSSION}

This study produces multimedia learning swimming for students. After going through the development stage, swimming learning multimedia is obtained that is valid, practical, and has potential effects on students. In this development process, researchers used Ellis and Levy's development model and Suparman's formative evaluation. Ellis and Levy 'development model consists of six stages, namely: 1) problem identification; 2) identification of objectives; 3) media design and development; 4) product testing; 5) evaluation; and 6) the publication in this research the researcher only did up to the evaluation stage which was carried out simultaneously with the product trial. The choice of Ellis and Levy development model in this study is because Ellis and Levy development model is a productoriented development model, especially for producing learning media. Whereas for the evaluation stage, the researcher used Suparman's formative evaluation model which consisted of several stages, namely: 1) expert evaluation; 2) one-toone evaluation; 3) small group evaluation; and 4) field testing (field test).

Learning multimedia validity data obtained by interview method. Expert evaluation (expert review) and aims to see the validity of the media. Expert review is a stage to see the validity of swimming multimedia learning developed by researchers. This stage aims to obtain a valid swimming learning multimedia learning design. Learning multimedia that has been produced is validated with a focus on three aspects, namely aspects of the material (content), learning design (construct), and media (lay out). The results of the interview are used as a reference for revising the product being developed. The results of the validation of all the aspects assessed were then concluded by the validator that the learning multimedia was valid and feasible to be tested with revisions according to the 
suggestions. It can be concluded that the multimedia learning swimming for students that the researchers developed is valid and can be used at the next research stage (Putra et al., 2020)

The one-to-one evaluation stage aims to see the practicality of prototype 1 that has been validated by experts. This stage involved 3 students individually, namely Yusuf Solehudin representing the high group, Rafy Wiranata representing the moderate group, and yoga for the low group. During the learning process the researcher communicates directly to the three students to see the difficulties faced by students and their responses to the multimedia learning Swimming. Based on the results of the interview, several suggestions and criticisms were obtained that could be used as a reference in revising the product being developed. In addition, based on the results of student opinions, it can be said that prototype 1 is good and is classified as a practical prototype to use (Okilanda, 2017)

The practicality of learning multimedia data was also obtained from questionnaires and observations. Questionnaires are used to obtain data about student responses and assessments of interactive multimedia designs. Observations in this study were used to collect data about student activities during class learning using interactive multimedia. Questionnaires and observations were used at the small group evaluation stage aimed at students

The small group stage is to see the practicality of multimedia learning in Swimming. This stage is carried out at the Garuda Swimming Pool, Jln Hang Tua, Palembang. The prototype 2 trial consisted of eight people, namely: Selvi, Mega, Heni, Fadrul, Iman, Yusuf, Redo, Abi, Akhlan. Students carry out learning activities using multimedia learning Swimming. At this stage students carry out learning activities using multimedia learning Swimming. At this stage, student activities during the learning process are observed. Based on the results of observations, it was obtained that the average student activity was $80.89 \%$ and classified as active, meaning that Swimming Learning multimedia was practical. 
At the end of the lesson at the small group stage, students are asked to fill out a questionnaire on their responses to prototype 2 that is being developed. Based on the average results of student responses to multimedia learning Swimming is $84.3 \%$. From the explanation above, it can be concluded that the use of multimedia learning in Swimming for Physical Education Study Program students is a very practical criterion (Putri et al., 2021)

The effectiveness of learning multimedia is measured using test instruments. The test is used to collect data on student learning outcomes in taking part in learning before and after using multimedia classes. The potential effects observed in the learning process at the field trial stage is an assessment of student learning outcomes that is carried out by providing learning outcomes tests.

The field test stage aims to see the potential effect of using swimming multimedia on student learning outcomes. The field test was held four times in the Garuda swimming pool. At the first meeting in the field test stage, an initial test was given to students with the aim of seeing how much initial knowledge the students had. The mean pretest result was $68.09 \%$, then the learning process was carried out using swimming multimedia learning. At the second, third and fourth meetings, learning was carried out using swimming multimedia learning.

At the end of the fourth meeting, a post-test was held with the aim of seeing the potential effects of swimming multimedia on learning outcomes. The mean posttest result is $84.35 \%$ with good category. The gain score obtained is 1.03 with the high category. This shows that there is an increase in student learning outcomes after using swimming multimedia learning.

Besides being effective for student learning outcomes, learning multimedia also increases student learning activity. This can be seen from the results of observations that produce an average of $76.00 \%$ which is classified as active. At the meeting each meeting experienced an increase in student activity.

Learning using swimming multimedia learning that has been developed can create meaningful activities for students, where students are easier to 
remember material and organize their knowledge, and attract students more in the learning process, because each concept presented is accompanied by videos, images, and various colors. which can clarify students' understanding of learning freestyle swimming. It can be concluded that the swimming multimedia learning that researchers developed has a potential effect on student learning outcomes.

The advantages contained in the swimming learning multimedia that were developed were: (a) multimedia learning Swimming is equipped with videos and animations that help students to understand the concept of freestyle swimming movements; (b) the content of the swimming multimedia learning that the researchers developed is complete because it contains clearly formulated competencies, indicators and learning objectives, study instructions, a summary of learning materials, exercises, tests to measure student mastery of the material being studied; (c) Students can study according to their respective abilities because this learning multimedia is designed for independent learning besides that students can repeat the material if it is not clear; (d) Easy to use by students (practical) and more effective in using time; (e) There is music that accompanies the learning process which makes the learning atmosphere more fun and less boring; (f) combining and simplifying complex materials (Nopianto et al., 2020)

There are several weaknesses in this study. This multimedia is made using Macromedia Flash 8, sometimes if your laptop or computer does not have flash software then there are some applications that cannot run, therefore it needs to be installed first. Text and video are more dominant in this learning multimedia so that students must be more concentrated and patient so that it is easier to understand the existing material. Some of the weaknesses contained in Learning multimedia are expected to be used as a reference for further researchers to revise them so that the resulting Learning multimedia is better.

\section{CONCLUSION}

Based on the results of the research that has been done, it can be concluded that multimedia swimming lesson is declared valid and feasible to test 
for tel ah do various stages and testing by the subject matter experts, media and instructional design.

Learning multimedia developed is also practical to be used and implemented because it is able to make students active in participating in learning, this can be seen in the one-on-one evaluation stage and the observation results obtained by an average student activity of $84.35 \%$ and classified as active. In addition, this can also be seen from the average results of student responses to the multimedia teaching and learning Swimming pool of $76.00 \%$ which is included in the very practical criteria. The use of multimedia learning can also increase student activity and learning outcomes and is effective to be used and used as a guide for lecturers and students in studying swimming material, especially freestyle, this can be seen from the results of the pretest with a pretest mean of $68.09 \%$ and postest with a mean postest of 84.35. There is an increase between the pre test and postest.

Based on the results of the research and the above conclusions, the suggestions can be given are for students to be more concentration in the use of multimedia swimming lesson text and video of his more dominant . For lecturers in the field of Swimming studies, in order to further improve their ability to use computer technology and use swimming multimedia learning. For other researchers, so that it can be used as a reference in developing better and perfect products.

\section{CONFLICT OF INTEREST}

There is no conflict between the author, manager of the journal, and the place of research during the registration process, review, until publication. 


\section{REFERENCES}

Anugrah, A., Ibrahim, N., \& Sukardjo, M. (2021). How Flipped Classroom Helps the Learning in the Times of Covid-19 Era? JTP - Jurnal Teknologi Pendidikan, 22(3), 151-158.

Alba, H. F., Mulyana, \& Subarjah, H. (2019). Pengaruh model latihan weight training dan motivasi latihan terhadap body fat dan body mass index (BMI). Jurnal Ilmu Keolahragaan, 18(2), 112-119.

Barlian, E. (2016). Metodologi Penelitian Kualitatif \& Kuantitatif. Sukabina Press.

Departemen Pendidikan Nasional. (2006). Kurikulum 2006 Standar Isi Pelajaran Renang. Jakarta: Depdiknas.

Gunawan, M., Putri, R., \& Zulkardi. (2017). learning Fractions through Swimming Context for Elementary School Students. Advamces in Social Science, Education and Humanities research. 100, pp. 61-65. Atlantis Press.

Lee, D., Morrone, A., \& Siering, G. (2018). From swimming pool to collaborative learning studio : pedagogy, space, and technology in large active learning classroom. Educational Technology Research and Development , 66(1), 95-127.

Nopianto, W., El Cintami Lanos, M., \& Arisman, A. (2020). The Effect of Mixed Inpact Aerobic Gymnam on The Improvement of Physical Fitness for High School. JIPES, 6(2), 55-61.

Okilanda, A. (2017). Analisis Pembelajaran Gerak Keterampilan ....( Ardo Okilanda). 7, 31-41.

Okilanda, A., Dlis, F., Humaid, H., Putra, D. D., Arisman, A., \& Muslimin, M. (2021). Defense Warm-Up Exercise Material for 13-Age Athlete Using Video Technology in Covid-19 Era. International Journal of Human Movement and Sports Sciences, 9(4), 629-634. https://doi.org/10.13189/saj.2021.090404

Putra, D. D., Okilanda, A., Arisman, A., Lanos, M. E. C., Putri, S. A. R., Fajar, M., Lestari, H., \& Wanto, S. (2020). Kupas Tuntas Penelitian Pengembangan Model Borg \& Gall. Wahana Dedikasi : Jurnal PkM Ilmu Kependidikan, 3(1), 46. https://doi.org/10.31851/dedikasi.v3i1.5340

Putri, R. A. S., Lanos, C. E. M., Lestari, H., \& Fajar, M. (2021). Student perception of the basic engineering learning model throught the play approach. Jurnal Halaman Olahraga NUsantara, 4(1), 114-124. https://doi.org/http://dx.doi.org/10.31851/hon.v4i1.5120 
Sihkabuden, S. P. (2005). Media Pembelajaran. Malang: Elang Mas.

Sugiyono. (2012). Metode Penelitian Pendidikan, Pendekatan Kuantitatif, Kualitatif, dan R\&D. Bandung: Alfabeta.

Septiani, M., \& Putra, D. D. (2020). Penerapan Blended Learning Pada Mata Kuliah Dasar-Dasar Pengembangan Kurikulum. Educate : Jurnal Teknologi Pendidikan, Vol. 5 No. 1, 96-109.

Taufik, M. S., Solahuddin, S., Arisman, A., Ridlo, A. F., \& Iskandar, T. (2021). Improve Learning Outcomes of Basketball Lay Up Shoot in Junior High School. COMPETITOR: Jurnal Pendidikan Kepelatihan Olahraga, 13(2), 154. https://doi.org/10.26858/cjpko.v13i2.19412 